\title{
BODY COMPOSITION AND PHYSIOLOGICAL CHARACTERISTICS OF LAW ENFORCEMENT OFFICERS
}

\author{
D. L. SPITLER, PhD, FACSM, G. JONES, MS, J. HAWKINS, EdD* and L. DUDKA, PhDt \\ School of HPERD, University of North Carolina at Greensboro, "Department of Sport Studies, Guildford College, Greensboro and \\ tDepartment of Physical Education, North Carolina A \& T State University, Greensboro, NC
}

\begin{abstract}
The physical work capacity, body composition, and physiological characteristics of 12 law enforcement officers (9 males, 3 females) were measured. Subjects included a representative sample from the occupational categories of detective, staff, investigative and patrol officer. Mean maximal oxygen uptake of the men was $42.1 \pm 8.9 \mathrm{ml}^{\circ} \mathrm{kg}^{-1} \mathrm{~min}^{-1}$ with mean values of $41.5 \pm 8.7 \mathrm{ml}^{\mathrm{kg}} \mathrm{kg} \mathrm{min}^{-1}$ for the women. Measurement of body composition indicated an average of $24.4 \pm 7.1 \%$ body fat for the men and $30.9 \pm 1.2 \%$ for the women. Muscular power, strength, and endurance as measured by isolated limb flexionextension movement and fitness test performance was considered average with no excessive bilateral differences. The results of this study were compared with other investigations of law enforcement officers of similar age groups. The officers displayed average or above health and physical fitness scores for their age classification and were able to complete all police task-oriented tests.
\end{abstract}

Key words: Maximal oxygen uptake, Cybex, Physical fitness, Police officers

\section{INTRODUCTION}

The current popular health and physical fitness interest has been incorporated into the law enforcement field with the recent adoption of various fitness testing programmes for officers. Most of the health and fitness programmes appear to have been initiated on the basis of subjective opinion of departments who have a genuine desire to reduce costs of health care, improve general health, reduce absenteeism, increase productivity and improve employee work attitude and job satisfaction (Bjurstome and Alexiou, 1978). Lack of knowledge of what constitutes a healthy, effective officer and time or financial constraints often restrict these programmes to simple tests of fitness which may or may not reflect the health or job performance capability of the individual officer. Before instituting a programme of Total Wellness which was to include both health status and performance evaluation, the Greensboro Police Department, NC, conducted a pilot test programme to provide information on a representative sample of officers. The present study describes the physical and physiological characteristics of law enforcement officers.

\section{METHODS}

Twelve officers ( 3 females, 9 males) of the Greensboro Police Department, Greensboro, NC volunteered to participate in the study. Mean age $( \pm S D)$ of the subjects was $32.4 \pm 4.7$ years with mean height $179.5 \pm 8.9 \mathrm{~cm}$ (men and $164.5 \pm 2.3 \mathrm{~cm}$ (women) while mean weight was $84.4 \pm$ $12.4 \mathrm{~kg}$ (men) and $60.8 \pm 2.9 \mathrm{~kg}$ (women). A fair representation of the various duties and job classifications of the department was an important factor in recruitment of subjects. Medical history review and examination were completed and informed consents obtained prior to the study.

The subjects participated in several test sessions at five test sites in which tests in the following areas were conducted: Medically-Oriented Health and Physical Fitness Tests, Standard Physical Fitness Tests and Police TaskOriented Performance Tests.

Address for correspondence:

Dr. D. L. Spitler

School of Health, Physical Education, Recreation and Dance

Department of Physical Education

The University of North Carolina

Greensboro

North Carolina 27412-5001

\section{Medically-Oriented Health and Physical Fitness Tests}

Body composition was assessed by body density (Brozek et al, 1963) and skinfold (triceps, subscapular, suprailiac, abdominal, thigh) techniques. A 12-lead electrocardiogram (ECG) and blood pressure were obtained after 10 minutes of supine rest. Standard pulmonary function evaluation consisted of forced vital capacity, forced expiratory volume in 1 second, and maximum voluntary ventilation. Coronary heart disease risk factors, dietary food habits, smoking habits, alcohol drinking habits, exercise habits, perceived stress, Type A Behaviour tendency (Falls et al, 1980) and self-esteem (Jaeger, 1985) were evaluated by questionnaires. Sensory integrity was evaluated by standard tests for reaction/movement time (hand-eye), kinesthetic recall (arm movement), peripheral visual range, and bone and air conduction hearing of a single tone. Fasting venous blood samples were analysed for glucose, total cholesterol, creatine phosphokinase, lactate dehydrogenase, serum glutamate pyruvate, haematocrit, haemoglobin and complete blood count. Maximal oxygen uptake $\left(\mathrm{VO}_{2}\right.$ max) was evaluated by a graded Bruce treadmill stress test to voluntary maximal exertion with continual monitoring of 3-lead ECG and collection of expired gases for calculation of ventilation, oxygen uptake and carbon dioxide production (Douglas Bag Method). Muscular power, strength, and endurance were assessed by standard Cybex II techniques for knee and shoulder flexion and extension. Strength was determined as maximum torque generated, power as maximum torque over a 0.25 period and endurance as percentage decrement in torque 15 s after attainment of peak torque at each standard movement speed.

\section{Standard Physical Fitness Tests}

Predicted maximal oxygen uptake was estimated using a cycle ergometer test with continual monitoring of a 3-lead ECG, the 3 Mile Walk and Cooper's 12-Minute Walk-Run Test. Speed was tested by the 50 yard dash and flexibility was evaluated with sit and reach back flexion. Muscular strength was measured with a grip strength dynamometer and a one repetition maximum (1 RM) bench press. Muscular endurance was evaluated with push-ups (maximum), chin-ups (maximum) and sit-ups (1 minute). Agility was measured with a dodging run (Gates and Sheffield, 1940) and muscular power by the vertical jump.

Police Task-Oriented Tests

These tests consisted of timed performance tests from the 
State of North Carolina Law Enforcement Guidelines (NC Justice Academy, 1985) and consisted of a 550 yard run, victim carry, window climb, 6 foot wall scale, long jump, 40 foot culvert crawl and uneven balance beam walk. In addition, a timed 165 yard obstacle course (Ellis et al, 1985) was completed.

\section{RESULTS}

Resting heart rates (72 \pm 12 beat.min-1) and blood pressures $(128 / 86 \pm 12 / 6 \mathrm{~mm} \mathrm{Hg})$ were within normal limits as were blood chemistries, cardiovascular heart disease risk profiles and pulmonary function measurements. Per cent body fat, as calculated from body density, averaged $24.4 \pm$ $7.1 \%$ for the men and $30.9 \pm 1.2 \%$ for the women. Fat free weight was calculated at $63.1 \pm 6.7 \mathrm{~kg}$ and $41.9 \pm 2.7 \mathrm{~kg}$ for the men and women, respectively. Sum of 5 skinfolds measured $77.3 \pm 26.2 \mathrm{~mm}$ (men) and $81.3 \pm 25.7 \mathrm{~mm}$ (women) with calculated per cent fat at $15.9 \pm 4.9 \%$ (men) and $19.1 \pm 5.8 \%$ (women). Nutrition was evaluated by food intake frequency and fat food intake was considered low to average as were alcohol consumption and exercise habits. Only one officer smoked. The police officers tended to demonstrate Type B personality behaviour tendencies with normal self-esteem ratings. Mean sensory integrity measurements (reaction time, movement time, kinesthetic recall, vision and hearing) were also considered within normal limits. Directly determined mean maximal oxygen uptake was $42.1 \pm 8.9 \mathrm{ml}^{\mathrm{kg}} \mathrm{g}^{-1} \mathrm{~min}^{-1}$ for the men and $41.5 \pm$ $8.7 \mathrm{ml}^{.} \mathrm{kg}^{-1} \mathrm{~min}^{-1}$ for the women.

Muscular power, strength, and endurance (Cybex technique) means are presented in Table I. No major differences were seen as a group in bilateral or in flexion/ extension ratio comparisons. All performance data is presented as total means with the three women's data included. Mean stàndard fitness test data are presented by fitness component in Table II. Bench press 1 RM produced

TABLEI

Muscular power, strength and endurance by Cybex Technique. Mean \pm SD

\begin{tabular}{|c|c|c|c|c|c|c|c|}
\hline \multirow{2}{*}{ Power } & \multirow{2}{*}{$\begin{array}{c}\text { Flexion } \\
\text { Watts }\end{array}$} & $\begin{array}{c}\text { Right } \\
\text { Extension }\end{array}$ & \multirow{2}{*}{ Ratio } & \multirow{2}{*}{$\begin{array}{c}\text { Flexion } \\
\text { Watts }\end{array}$} & \multicolumn{2}{|c|}{$\begin{array}{l}\text { Left } \\
\text { Extension }\end{array}$} & \multirow{2}{*}{$\frac{\text { Ratio }}{\%}$} \\
\hline & & Watts & & & & & \\
\hline \multirow[t]{2}{*}{ Shoulder } & 144.4 & 275.2 & 52.5 & 143.7 & & & 56.5 \\
\hline & 61.5 & 68.5 & & 77.3 & & & \\
\hline \multirow[t]{2}{*}{ Knee } & 347.5 & 523.5 & 66.4 & 308.5 & & & 66.6 \\
\hline & 100.5 & 177.0 & & 103.0 & & & \\
\hline Strength & \multicolumn{2}{|c|}{ Newton Meters } & $\%$ & \multicolumn{3}{|c|}{ Newton Meters } & $\%$ \\
\hline \multirow[t]{2}{*}{ Shoulder } & 29.9 & 44.2 & 67.6 & 28.4 & & & 67.0 \\
\hline & 6.4 & 11.7 & & 8.7 & & & \\
\hline \multirow[t]{2}{*}{ Knee } & 65.2 & 106.8 & 61.0 & 60.4 & \multirow{2}{*}{\multicolumn{2}{|c|}{$\begin{array}{r}109.8 \\
39.0\end{array}$}} & 55.0 \\
\hline & 19.5 & 28.5 & & 16.8 & & & \\
\hline Endurance & $\begin{array}{c}\% \text { strength } \\
\text { at } 15 \text { rep }\end{array}$ & \multicolumn{2}{|c|}{$\begin{array}{l}\% \text { strength } \\
\text { at } 15 \text { rep }\end{array}$} & \multicolumn{2}{|c|}{$\begin{array}{l}\% \text { strength } \\
\text { at } 15 \text { rep }\end{array}$} & \multicolumn{2}{|c|}{$\begin{array}{c}\% \text { strength } \\
\text { at } 15 \text { rep }\end{array}$} \\
\hline \multirow[t]{2}{*}{ Shoulder } & 64.5 & \multicolumn{2}{|c|}{67.2} & \multicolumn{2}{|c|}{53.0} & \multicolumn{2}{|c|}{63.5} \\
\hline & 18.9 & \multicolumn{2}{|c|}{16.9} & 20. & & \multicolumn{2}{|c|}{17.1} \\
\hline \multirow[t]{2}{*}{ Knee } & 65.4 & \multicolumn{2}{|c|}{62.6} & 70. & & \multicolumn{2}{|c|}{66.3} \\
\hline & 14.9 & \multicolumn{2}{|c|}{12.1} & 25. & & \multicolumn{2}{|c|}{17.6} \\
\hline
\end{tabular}

great individual variation with a mean of $64.3 \pm 28.9 \mathrm{~kg}$. Sit and reach measurements averaged $45.0 \pm 6.1 \mathrm{~cm}$ or $6.9 \mathrm{~cm}$ beyond the feet. In addition, mean distance for the 12 minute walk/run was $2.1 \pm 0.3 \mathrm{~km}$ and mean time for the 3 mile walk $(4.8 \mathrm{~km})$ was $45.1 \pm 6.9$ minutes.

TABLE II

Selected standard physical fitness test items. Mean \pm SD

\begin{tabular}{|c|c|c|c|c|c|c|c|c|}
\hline \multicolumn{4}{|c|}{ Strength } & $\begin{array}{c}\text { Muscle } \\
\text { Endurance }\end{array}$ & Power & Agility & Speed & Flexibility \\
\hline $\begin{array}{l}\text { Grip } \\
\text { Str. } \\
\text { kg }\end{array}$ & $\begin{array}{l}\text { Push } \\
\text { Ups }\end{array}$ & $\begin{array}{l}\text { Chin } \\
\text { Ups }\end{array}$ & $\begin{array}{c}\text { Bench } \\
\text { Press } \\
1 \text { RM } \\
\text { kg }\end{array}$ & $\begin{array}{l}\text { Sit } \\
\text { Ups }\end{array}$ & $\begin{array}{c}\text { Vertical } \\
\text { Jump } \\
\text { cm }\end{array}$ & $\begin{array}{l}\text { Agility } \\
\text { Run } \\
\text { sec }\end{array}$ & $\begin{array}{c}50 \text { Yard } \\
\text { Dash } \\
\text { sec }\end{array}$ & $\begin{array}{c}\text { Flexibility } \\
\text { Back } \\
\text { cm }\end{array}$ \\
\hline 24.1 & 27.2 & 5.0 & 64.3 & 31.8 & 42.4 & 8.1 & 7.3 & 45.0 \\
\hline 6.1 & 13.5 & 4.1 & 28.9 & 7.2 & 9.7 & 0.6 & 0.5 & 6.1 \\
\hline
\end{tabular}

\section{TABLE III}

Police task-related performance selected items. Mean \pm SD

\begin{tabular}{|c|c|c|c|c|c|c|c|}
\hline $\begin{array}{c}550 \text { Yard } \\
\text { Run } \\
\text { min }\end{array}$ & $\begin{array}{c}165 \text { Yard } \\
\text { Obstacle } \\
\text { Run } \\
\text { sec }\end{array}$ & $\begin{array}{c}\text { Victim } \\
\text { Carry } \\
\text { sec }\end{array}$ & $\begin{array}{c}\text { Window } \\
\text { Climb } \\
\text { sec }\end{array}$ & $\begin{array}{c}6 \text { Foot } \\
\text { Wall } \\
\text { Scale } \\
\text { sec }\end{array}$ & $\begin{array}{c}\text { Running } \\
\text { Long } \\
\text { Jump } \\
\text { m }\end{array}$ & $\begin{array}{c}40 \text { Foot } \\
\text { Culvert } \\
\text { Crawl } \\
\text { sec }\end{array}$ & $\begin{array}{c}\text { Uneven } \\
\text { Balance } \\
\text { Beam } \\
\text { Walk } \\
\text { sec }\end{array}$ \\
\hline 2.2 & 41.8 & 14.2 & 3.1 & 4.8 & 3.1 & 13.2 & 4.5 \\
\hline 0.4 & 4.6 & 6.8 & 0.8 & 2.5 & 0.5 & 4.7 & 0.9 \\
\hline
\end{tabular}

Mean times of completion for each police task-oriented test are presented in Table III. All subjects were able to complete the tasks although some required a longer time period or several attempts to master the technique.

\section{DISCUSSION}

Comprehensive and mandatory physical fitness programmes are becoming increasingly common in the law enforcement setting. Most of these make the assumption that an officer who is in shape will be able to respond to occupational demands without undue probability of injury, illness, or death. In addition, an assumption is made in the law enforcement field in that a police officer is supposed to be well above average in all physical attributes: bigger, stronger, quicker, more healthy than the average person. However, the officers in the present study could be best described as typical, average individuals.

Comparison with published norms from other police departments or agencies showed that the subjects in this study were representative of law enforcement personnel. The mean age was $32.4 \pm 4.7$ years which was similar to the mean of 35-39 years reported in an investigation sampling $10 \%$ of the entire Pennsylvania State Police Agency (Fraser, 1986).

\section{Basic Health Status}

A pre-requisite in maintaining a positive health status is weight control, or more correctly body composition balance. Percentage body fat values were similar to published values of $16.1-25.4 \%$ for officers aged $30-39$ years (Davis and Stark, 1980; Fraser, 1986; Stamford et al, 1977; NC Justice Academy, 1985; Kuntz, 1986; NC Alcohol Law Enforcement Division, 1986). Most of the values reported in 
this literature for per cent body fat were estimated from measures of skinfold thicknesses. Both the body density and the skinfold measurement techniques were utilised in the present study. There was a striking difference in the results of the two techniques with the values estimated from skinfolds extremely low for age group comparison.

\section{Cardiopulmonary Status}

Another basic concept for health is a stable resting cardiovascular status which is usually addressed by evaluation of a 12-lead ECG and blood pressure. The mean resting heart and blood pressure for the officers in the present study, as previously stated, were all within normal adult limits and within the limits of published law enforcement norms (Fraser, 1986; NC Justice Academy, 1985). ECG analysis has traditionally been recognised as an effective tool for evaluation of health status. However, published information (SC Criminal Justice Academy, 1986) is somewhat limited, probably due to the costs of such tests. As high blood pressure has been associated with increased risk of cardiovascular heart disease, its measurement has been recognised as a major factor in medical screening processes either for employment requirements or yearly fitness testing at law enforcement agencies (Ellis and Bailey, 1984; Ellis et al, 1985; Gayle, 1978; SC Criminal Justice Academy, 1986).

The evaluation of stress test ECG data (SC Criminal Justice Academy, 1986; Gayle, 1978; Mostardi et al, 1986) and direct measurement of maximal oxygen uptake is also rare in the law enforcement field. $\mathrm{Mean}_{\mathrm{V} \mathrm{O}_{2}}$ max measured in the present study compared favourably with the 36.6-40.1 $\mathrm{ml} . \mathrm{kg}^{-1} \mathrm{~min}^{-1}$ average oxygen uptake reported for officers and 30-39 years using the same treadmill protocol (Price et al, unpublished data).

Submaximal stress tests of various kinds to predict maximal oxygen uptake have become quite popular. The officers in the present study participated in three predictive tests and the results of these tests compared favourably with published test results (Stamford et al, 1977; NC Justice Academy, 1985; Ahlstrom, 1985).

\section{Musculo-Skeletal Integrity Status and Performance}

A unique feature of the present study is the assessment of musculo-skeletal integrity by isolation of flexion and extension of the shoulder and knees combined with performance data from fitness tests of muscular performance. Mean power, strength, and endurance values are reported in Table I. It has been proposed that imbalances between flexion-extension and right-left limbs might indicate a potential for high risk of injury. The police officer tends to have very sedentary task demands during the majority of his/her shift but there is always the risk of emergency situations requiring maximal exertion of muscular effort. An imbalance in limb strength might cause the officer to sustain significantly unequal forces across the knees or back resulting in injury. The same would be true if extension was excessively greater than flexion in any one limb. Interestingly, the endurance ratios of strength after 15 repetitions were similar in both the knee and shoulder in spite of lower maximal strength and power measures in the shoulder (Table I). This could be a good sign for the overall exercise conditioning reported in the exercise profiles of the officers and may indicate a reduced injury risk. Experimental studies are needed to explore the critical flexion-extension ratio for injury risk. No major imbalances were evident in the present study nor could published Cybex data on police officers be located.
Comparison of the results of standard physical fitness scores of the officers of the present study (Table II) to scores of fellow officers of similar age is somewhat difficult due to the diverse types of tests that can be used to assess physical fitness. In general, the mean scores achieved were typical of the mean scores reported for other law enforcement populations (Davis and Stark, 1980; NC Justice Academy, 1985; Ahlstrom, 1985; Fraser, 1986; Booth and Hornick, 1984).

As job-relevancy is an important consideration, many departments and agencies have developed police taskoriented tests (Fraser, 1986; Booth and Hornick, 1984; Ellis et al, 1985; Gayle, 1978; NC Justice Academy, 1985). These tests are generally combinations of basic movements that might occur during a patrol officer's duties such as climbing a fence or wall, pursuing a suspect, jumping, or carrying a victim to safety. The tests selected for the present study were part of the State of North Carolina Law Enforcement Guidelines (NC Justice Academy, 1985) although instead of conducting a run through the entire course, each event was individually timed. In addition, a 165 yard obstacle course was selected (Ellis et al, 1985). The results of the taskoriented tests are presented in Table III and do not necessarily match any test battery selected by any other agency. Each agency who elects to utilise task-oriented measures for officer fitness has to decide on the activities to be evaluated, the order and combination of events, and establish their own norms for acceptable performance. Lack of normative data is a limitation in interpreting results for officers and for the department. The basic premise of taskoriented tests is a "can do" or "cannot do" evaluation. In this respect, the majority of the officers in the present study completed each task successfully.

\section{CONCLUSION}

The results of this study indicate that this representative population of police officers can be described as healthy and physically fit. Most are coping well with the potential health problems of a sedentary job, changing shift work times, and emotionally charged emergency duties. They can be placed well along the positive axis of a healthdisease continuum.

\section{ACKNOWLEDGEMENTS}

The authors wish to acknowledge the assistance of the Clinical Laboratory, Wesley Long Community Hospital; Law Training Academy, Guildford Technical and Community College; Dr. Spenser Tilley, MD; and C. D. Wade, Chief, and the Greensboro Police Department for support in this project.

\section{References}

Ahlstrom, P. C., 1985 "Police memorandum". Department of Public Safety Broomfield, $\mathrm{CO}$.

Bjurstrom, L. A. and Alexiou, N. G., 1978 "A program of heart disease intervention for public employees". J.Occup.Med. 20 (8): 521-531.

Booth, W. S. and Hornick, C. W., 1984 "Physical ability testing for police officers in the 80's". The Police Chief Jan: 39-41.

Brozek, J., Grande, F., Anderson, J. T. and Keys, A., 1963 “Densiometric analysis of body composition: a revision of some quantitative assumptions". Ann.NY Acad.Sci. 110: 113-140.

Davis, P. O. and Stark, A. R., 1980 "Age vs. fat: effect on physical performance of police officers". FBI Law Enforcement Bulletin Sept: 10-15.

Ellis, T. L. and Bailey, R., 1984 "Healthy police officers are cost-effective police officers". Police Management Today: 201-206. 
Ellis, T. L., Brown, K., Sutton, E., White, K. and Bailey, R., 1985 "Physical fitness program". Monterey Police Department, Monterey, CA.

Falls, H. B., Baylor, A. M. and Dishman, R. K., 1980 "Essentials of fitness". W. B. Saunders Publishers: Philadelphia, PA.

Fraser, E. A., 1986 "Physical fitness maintenance: a developmental process". The Police Chief Jn: 24-27.

Gates, D. P. and Sheffield, R. P., 1940 "Tests of change of direction as measurement of different kinds of motor ability in boys of the 7th, 8th and 9th grades". Research Quarterly 11 (3): 136-147.

Gayle, R. C., 1978 "The department of energy physical fitness qualifications test for security inspectors: analysis and recommendations". Union Carbide Corporation, Oak Ridge, TN.

Jaeger, R. M., 1985 "Self-esteem scale". (Unpublished data), University of North Carolina at Greensboro, NC
Kuntz, G. F., 1986 "Development and implementation of glynco's physical assessment test". The Police Chief Nov: 22-30.

Mostardi, R. A., Porterfield, J. A., King, S., Wiedman, K. and Urycki, S., 1986 "Cardiovascular intervention among police officers: a two year report". The Police Chief Jn: 32-34.

North Carolina Alcohol Law Enforcement Division, 1986 “Wellness program handbook". Raleigh, NC.

North Carolina Justice Academy, 1985 “North Carolina law enforcement fitness standards and guidelines". Salemburg, NC.

South Carolina Criminal Justice Academy, 1986 "Health fitness screening project". South Carolina Criminal Justice Academy.

Stamford, B. A., Kley, J., Thomas, D. and Nevin, J., 1977 "Physical fitness criteria - an avant garde approach". The Police Chier Jan: 59, 70-71, 77.

\title{
BOOK REVIEW
}

\author{
Title: \\ CLINICAL APPLICATION \\ Editor: \\ Publisher: \\ James S. Skinner \\ Lea and Febiger, Philadelphia 1987 UK Agents: Quest Meridien, Beckenham \\ Price: $\$ 30.00$ US $\quad 314$ pages with Index, Tables and many References
}

\section{EXERCISE TESTING AND EXERCISE PRESCRIPTION FOR SPECIAL CASES - THEORETICAL BASIS AND}

ISBN 0812110544

This text makes a magnificent contribution to the literature on exercise testing. It does so by presenting a collection of individual chapters, written by authorities in the field, each one considering a different aspect of testing or special population.

Each of the chapters is presented economically yet in depth, well referenced and up-to-date. The first section on general considerations includes general principles, sexual dimorphism, aspects of age and environment. The second section on special cases includes rheumatoid arthritis, diabetes, dyslipoproteinemia, obesity, respiratory and cardiovascular conditions, and pregnancy. Sadly my review copy contained a serious printing error which duplicated two chapters and omitted two others. I was, therefore, not able to examine the special cases of rheumatoid arthritis and diabetes, but trust the printers have corrected this problem.

It is difficult to fault such an authoritative text and for any serious student of exercise testing and prescription, particularly considerations of special subjects, this book would be a valuable addition to their library.

David A. Brodie

\section{BOOK REVIEW}

\section{Title: $\quad$ THE ANTERIOR CRUCIATE DEFICIENT KNEE (NEW CONCEPTS IN LIGAMENT REPAIR)}
Authors:
D. W. Jackson and D. Drez Jnr.
Publisher:

$\begin{array}{ll}\text { C. V. Moseby } & 1987 \\ \text { Price: } f 50.50 & \text { UK Agent: Blackwell Scientific Publications } \\ \text { 324 pages with Index } & \text { ISBN } 0801624118\end{array}$

This book is a collection of papers written by faculty members from courses organised in America by the two editors. Douglas Jackson is the Medical Director of the Southern California Centre for Sports Medicine, Long Beach, California, whilst David Drez is the director of the Louisiana State University, Knee and Sports Medicine Fellowship programme.

The book is well laid out with clear diagrams. Chapters start with the anatomy of the anterior cruciate, details of the biomechanics, clinical examination of the knee for anterior cruciate ligament laxity followed by discussion on factors affecting the choice of anterior cruciate ligament surgery and extensive documentation on autograft, allograft and prosthetic ligament replacement both by open surgery and arthroscopic techniques. The final chapters deal with rehabilitation and the role of bracing.

As in the case of any multi-author volume certain subjects are omitted or glossed over in a very cursory manner. Such is the case in this volume where the menisci warrant eight lines of text with no mention of the pattern of meniscal injury that occurs with anterior cruciate damage whilst ten pages are given over to the quantitative examination of anterior cruciate laxity using the UCLA portable instrumentation.

The American surgeons at present seem to be mesmerised by biomechanics and testing under laboratory conditions whilst not fully assessing the functional result. The chapter on rehabilitation, gives the principles that immobility must be minimised and healing tissues must never be over-loaded, with great detail on the isometric phase, the isotonic phase, isokinetic phase and endurance phase programmes, yet the only mention of proprioceptive retraining is given one line. It is interesting to pick up the vibes that our American colleagues are dissatisfied with all the braces at present in use and in his summary on the future of anterior cruciate surgery Douglas Jackson admits that bracing has been primarily on an empirical basis and that more information is needed on its efficacy.

This book is aimed at the training and established orthopaedic surgeon with a specific interest in knee injuries. For this group it will provide stimulation and reference but it does demand a fair knowledge of the subject and is not for the casual browser. 